\title{
The Trend of Acute Respiratory Infections in Children Under 5 Years of Age in The Buton Tengah District, Indonesia
}

\author{
Ramadhan Tosepu', Mujamil Mujamil ${ }^{2}$ \\ \{ramadhan.tosepu@uho.ac.id ${ }^{1}$, mujamilskep@gmail.com ${ }^{2}$ \} \\ ${ }^{1}$ Faculty of Public Health, Halu Oleo University, Kendari, Indonesia \\ ${ }^{2}$ The postgraduate Program, Halu Oleo University, Indonesia and Dinas Kesehatan, Kabupaten \\ Buton Tengah, Sulawesi Tenggara, Indonesia
}

\begin{abstract}
ARI is an Acute Respiratory Tract Infection that comes suddenly, which is short and severe. ARI can become Pneumonia or often called pneumonia, which is a coughing disease characterized by rapid breathing or shortness of breath. ARI is still one of the leading public health problems. This is due to the high mortality rate due to ARI, especially in infants and toddlers. This type of research is descriptive with Time Series analysis method. In conclusion, the upper ARI patients are most commonly found in the age group 12- $<60$ months. The incidence of ARI in Buton Tengah tends to decrease from year to year. Children who experience the most ARI are $1-<5$ years.
\end{abstract}

Keywords: Acute Respiratory Infections, Children, Southeast Sulawesi, Indonesia.

\section{Introduction}

ARI is often mistaken for an upper respiratory tract infection [1]. ARI is a respiratory tract infection that is anatomically distinguished from the upper airway from the nose to the fangs and lower respiratory tract starting from the larynx to the alveoli and its annex, due to the invasion of infecting agents that result in inflammatory airway reactions involved [2]. Until now, more than 300 types of bacteria and viruses have been identified as the cause of ARI.

The incidence of ARI in Buton Tengah has decreased from 2015 - 2018. In 2015 the incidence of ARI in infants reached $29 \%$. In 2016 the incidence of ARI in infants is still constant at $29 \%$. In 2017 ARI disease in infants decreased by $21 \%$. And it declined again in the following year 2018 which is $14 \%$. Related to the incidence of ARI in Buton Tengah, all sub-districts in Buton Tengah were detected to have ARI in infants [3]. The causes of ARI are diverse, but the most common causes are viral and bacterial infections [4]. ARI consists of more than 300 types of bacteria, viruses, and rickets. Bacteria that cause ARD include genera Streptococci, Staphylococci, Pneumococci, Hemophilus [5],[6]. ARI virus consists of the group Micosovirus, Coronavirus, Picornavirus, Mycoplasma, Herpesvirus [7]. In 2015 there were 13 cases of ARI disease in Wamolo sub-district, Buton Tengah district. Some of the symptoms experienced by toddlers include coughing, hoarseness while talking, runny nose, and fever. 


\section{Method}

This type of research is descriptive with Time Series analysis method. The population in this study was data of the ARI sufferers in children starting at five years in Buton Tengah District in the years 2015-2018. The data collected are secondary data, namely data on ARI sufferers obtained from monthly records of the ARI eradication and prevention program from January 2015 to December 2018 at the Buton Tengah Health Office.

\section{Results}

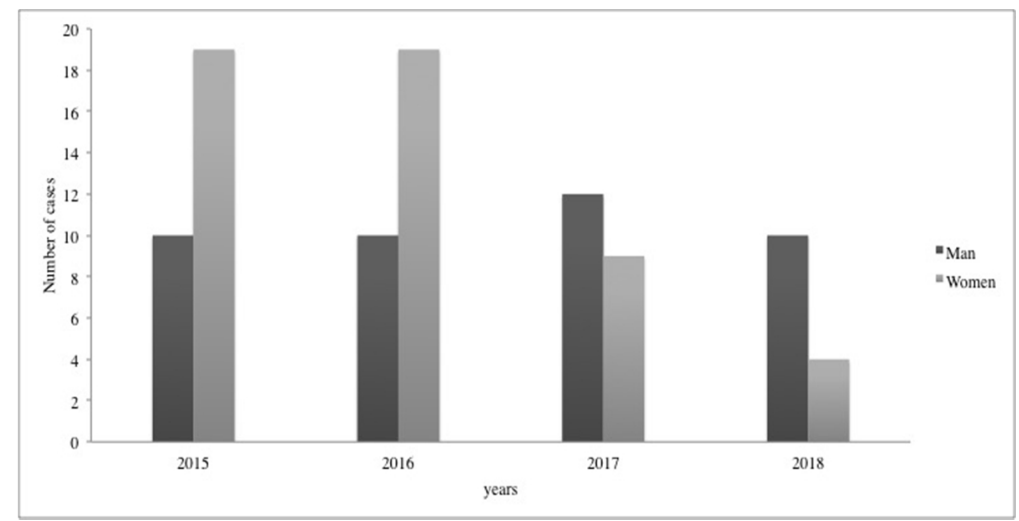

Figure 1. Report of the cases of Acute Respiratory Infections by gender

The results of the study show that based on sex, from 2015 to 2018 the distribution of patients with ARI more often affects women. In 2015-2016 the distribution of patients with ARI was the same for both men and women. Handling of efforts to reduce ARI incidence from year to year has decreased, and this shows that the management of ARI in Buton Tengah has succeeded in reducing the rate of ARI in infants in Buton Tengah district in 2018, (Figure 1). 


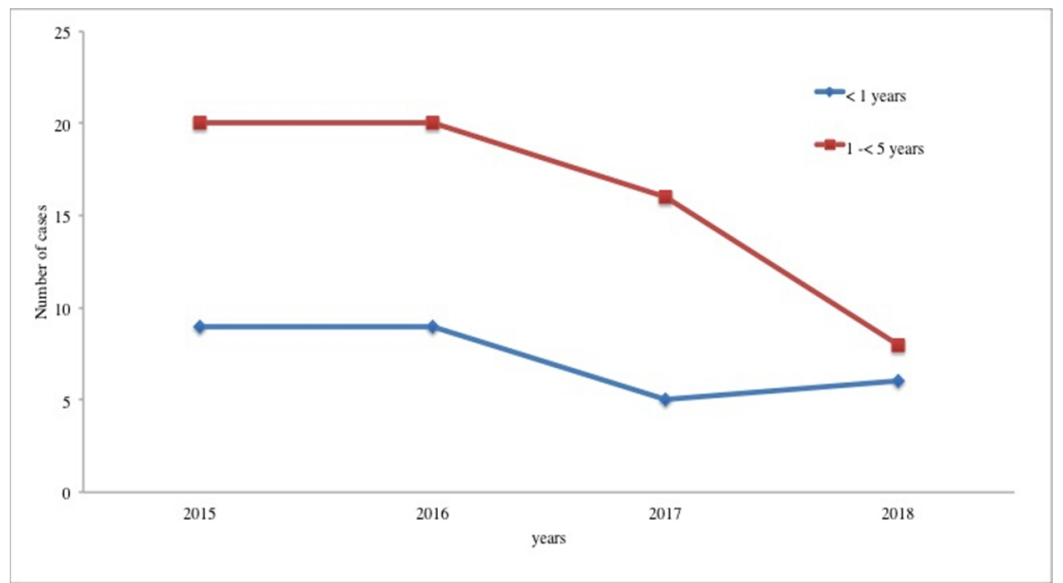

Figure 2. Report of the cases of Acute Respiratory Infections under five years

Based on the age distribution of toddlers who have ARI disease is toddlers aged $1-<5$ years. In 2015-2016 the distribution of toddlers who had the most ARI was equal to $20 \%$ at ages $1-5$ years, in 2017 the incidence of ARI in toddlers decreased to $16 \%$, namely at ages $1-<5$ years while in 2018 experienced decrease is $8 \%$ at ages $1-<5$ years. Whereas at the age of $<1$ year in 2015 and 2016 the distribution of children under five with ARI was 9\%, in 2017 the incidence of ARI in children under five decreased by $5 \%$ and in 2018 the placement of children with ARI increased to $6 \%$, (Figure 2).

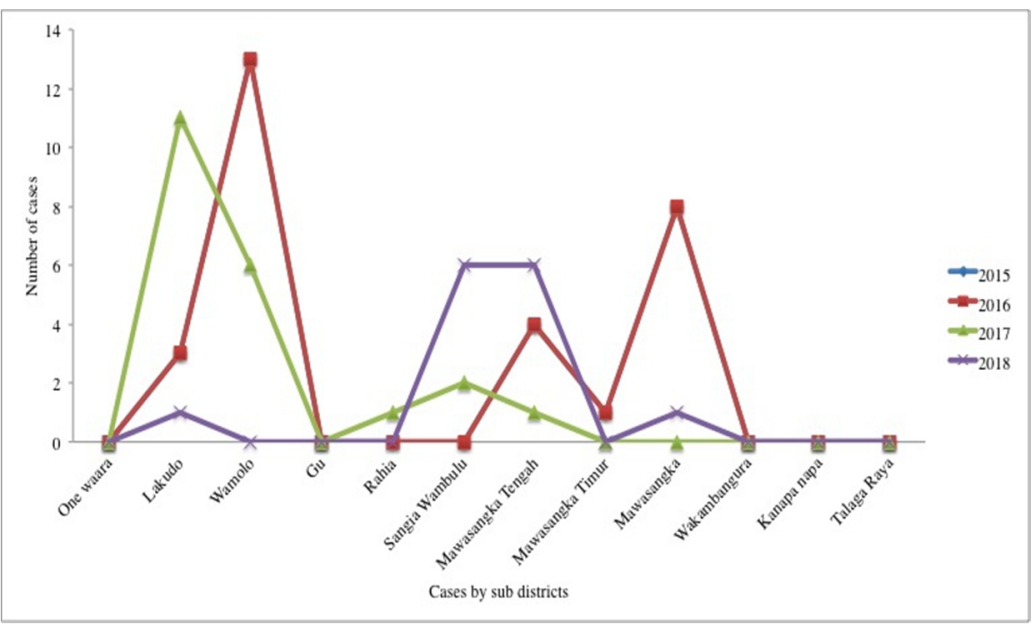

Figure 3. Distribution of the cases of Acute Respiratory Infections 
Based on the sub-district area in Buton Tengah district, it was found that in 2015 and 2016 the incidence of ARI in infants was most prevalent in the Wamolo sub-district, in 2017 the highest rate of ARI in infants was in the Lakudo sub-district, while in 2018 the highest frequency happening in the region of the sub-district Sangia Wambulu, and Mawasangka Tengah, (Figure 3).

\section{Discussion}

ARI is an acute inflammation of the upper and lower respiratory tract caused by infection with microorganisms or bacteria, viruses, without or accompanied by inflammation of the lung parenting [8]. The upper ARI is generally caused by a virus, while the lower ARI can be caused by bacteria and viruses [9]. The lower ARI caused by bacteria usually has severe clinical manifestations that cause several problems in its treatment [10]. Meanwhile, other factors in the occurrence of ARI include LBW (mild birth weight), malnutrition, indoor air pollution, not getting full breast milk, dense occupancy, incomplete immunization and deficiency of vitamin A [11].

ARI starts when microorganisms or foreign substances such as drops of liquid are inhaled, enter the lungs and cause inflammation. If the cause is a virus or bacteria, fluid is used by attacking organisms for development media. If the reason is a foreign substance, the liquid provides a growing place for plants that already exist in the lungs or respiratory system [12]. Rehabilitation in preventing the occurrence of ARI disease can be done with physical rehabilitation if there are physical health problems due to ARI [13],[14]. Maintain good nutritional condition, immunization, maintain personal and environmental cleanliness, and prevent children from dealing with ARI sufferers [15]. Treatment includes supportive treatment and antibiotics [16]. The most common cause of ARI is a viral infection, so antibiotics for this infection are not rational except for sinusitis, exudative tonsillitis, exudative pharyngitis and inflammation of the middle ear [17],[18].

Treatment of patients with ARI is intended to prevent the continuation of mild ARI to moderate ISPA and ARI is becoming a severe ARI and reduce severe ARI mortality. Treatment of ARI disease can also be done in several ways, one of which is to treat patients in the hospital. If treatment for all children with chest wall withdrawal is not possible, consideration can be given to antibiotic therapy at home with close supervision in children who do not experience severe chest wall withdrawal, cyanosis, or signs of very severe disease [19].

\section{Conclusion}

The upper ARI patients are found mostly in the age group 12- $<60$ months, which is more common in boys than in girls with a ratio of 1.2: 1. The incidence of ARI in Buton Tengah tends to decrease from year to year. Children who experience the most ARI are $1-<5$ years.

\section{Reference}

[1] R. E. Checon, M. M. Siqueira, A. K. Lugon, S. Portes, and R. Dietze, "seasonal pattern of respiratory syncytial virus in a region with a tropical climate in southeastern Brazil," The American journal of tropical medicine and hygiene, vol. 67, pp. 490-491, 2002. 
[2] P. Brotons, C. Launes, M. Iñigo, N. Peris, L. Selva, and C. Muñoz-Almagro, "Performance of a rapid multi-analyte 2-photon excitation assay in children with acute respiratory infection," Diagnostic Microbiology and Infectious Disease, vol. 79, pp. 190-193, 2014/06/01, 2014.

[3] D. K. B. Tengah, "Health Profile in Buton Tengah district", 2017.

[4] T. Matsumoto, K. Matsumura, K. S. Anwar, A. H. Mollah, N. Nahar, H. Murakami, et al., "Prevalence of Chlamydophila pneumoniae among Bangladeshi children under age 5 years with acute respiratory infections," Journal of Infection and Chemotherapy, vol. 12, pp. 139144, 2006/01/01, 2006.

[5] L. P.-C. Shek and B.-W. Lee, "Epidemiology and seasonality of respiratory tract virus infections in the tropics," Paediatric Respiratory Reviews, vol. 4, pp. 105-111, 2003/06/01, 2003.

[6] A. M. Hart and K. M. Morgan, "Acute Respiratory Infection-Related Patient Behaviors and Expectations in Wyoming," The Journal for Nurse Practitioners, vol. 9, pp. 202-207, 2013/04/01, 2013.

[7] S. Banerjee, P. Bharaj, W. Sullender, S. K. Kabra, and S. Broor, "Human metapneumovirus infections among children with acute respiratory infections seen in a large referral hospital in India," Journal of Clinical Virology, vol. 38, pp. 70-72, 2007/01/01, 2007.

[8] L. Wei, K. H. Chan, D. K. M. Ip, V. J. Fang, R. O. P. Fung, G. M. Leung, et al., "Burden, seasonal pattern and symptomatology of acute respiratory illnesses with different viral aetiologies in children presenting at outpatient clinics in Hong Kong," Clinical Microbiology and Infection, vol. 21, pp. 861-866, 2015/09/01, 2015.

[9] K. F. O'Grady, K. Grimwood, T. P. Sloots, D. M. Whiley, J. P. Acworth, N. Phillips, et al., "Prevalence, codetection and seasonal distribution of upper airway viruses and bacteria in children with acute respiratory illnesses with cough as a symptom," Clinical Microbiology and Infection, vol. 22, pp. 527-534, 2016/06/01, 2016.

[10] E. D. Shapiro, "Epidemiology of acute respiratory infections," Seminars in Pediatric Infectious Diseases, vol. 9, pp. 31-36, 1998/01/01, 1998.

[11] N. Z. Janjua, B. Mahmood, V. K. Dharma, N. Sathiakumar, and M. I. Khan, "Use of biomass fuel and acute respiratory infections in rural Pakistan," Public Health, vol. 126, pp. 855-862, 2012/10/01, 2012.

[12] S. Berman, "Epidemiology of acute respiratory infections in children of developing countries," Reviews of infectious diseases, vol. 13, pp. S454-S462, 1991.

[13] A. C. o. S. Medicine, ACSM's guidelines for exercise testing and prescription: Lippincott Williams \& Wilkins, 2013.

[14] S. C. Smith, E. J. Benjamin, R. O. Bonow, L. T. Braun, M. A. Creager, B. A. Franklin, et al., "AHA/ACCF secondary prevention and risk reduction therapy for patients with coronary and other atherosclerotic vascular disease: 2011 update: a guideline from the American Heart Association and American College of Cardiology Foundation endorsed by the World Heart Federation and the Preventive Cardiovascular Nurses Association," Journal of the American college of cardiology, vol. 58, pp. 2432-2446, 2011.

[15] W. H. Organization, "Facts about WHO", 1990.

[16] R. Gonzales, C. A. Camargo Jr, T. MacKenzie, A. S. Kersey, J. Maselli, S. K. Levin, et al., "Antibiotic treatment of acute respiratory infections in acute care settings," Academic emergency medicine, vol. 13, pp. 288-294, 2006. 
[17] D. Kibuule, H. R. Kagoya, and B. Godman, "Antibiotic use in acute respiratory infections in under-fives in Uganda: findings and implications," Expert review of anti-infective therapy, vol. 14, pp. 863-872, 2016.

[18] S. D. Persell, M. W. Friedberg, D. Meeker, J. A. Linder, C. R. Fox, N. J. Goldstein, et al., "Use of behavioral economics and social psychology to improve treatment of acute respiratory infections (BEARI): rationale and design of a cluster randomized controlled trial [1RC4AG039115-01]-study protocol and baseline practice and provider characteristics," BMC infectious diseases, vol. 13, p. 290, 2013.

[19] R. A. Pauwels, A. S. Buist, P. M. Calverley, C. R. Jenkins, and S. S. Hurd, "Global strategy for the diagnosis, management, and prevention of chronic obstructive pulmonary disease: NHLBI/WHO Global Initiative for Chronic Obstructive Lung Disease (GOLD) Workshop summary," American journal of respiratory and critical care medicine, vol. 163, pp. 12561276,2001 